\title{
Linguistic Colonialism in the English Language Textbooks of Multinational Publishing Houses
}

\author{
Colonialismo lingüístico en los libros de texto de inglés \\ de las editoriales multinacionales
}

\author{
Soto-Molina, Jairo Eduardo ${ }^{1}$, \\ Méndez, Pilar ${ }^{2}$
}

\begin{abstract}
The purpose of this paper is to examine and compare the concepts of linguistic colonialism and cultural alienation in University textbooks for teaching English as opposed to the theories about culture in the decolonial turn. Dichotomous categories were established based on the analysis of the cultural component of the textbooks for the teaching of English. The corpus consisted of six textbooks produced by multinational publishers and used in Colombia during the years 2006-2018. Documentary analysis procedures were used to discuss emergent themed contents in relation to cultural components from a critical perspective that unveiled imperialism practices. Results showed that the textbook contents dealt with high levels of alienation burden, superficial cultural components and instrumentation to the submissive person who favors the dominant culture of English and does not offer possibilities to embrace interculturality in ELF teaching contexts.
\end{abstract}

Jairo Eduardo Soto-Molina studied Social Research at Newbury College, Massachusetts, USA. Postgraduate Diploma in Epistemological Paradigms of Qualitative and Quantitative Research at Instituto de Estudios Avanzados (IAEU). He studied Teaching English to children at the University of California, San Diego, California. Master in Education, University of Antioquia, Medellin, Colombia. PhD in Human Sciences, University of Zulia Maracaibo, Venezuela. languagecircle.re@hotmail.com http://orcid.org/0000-0003-3378-0202

2 Pilar Méndez is a Doctor in Education from Universidad Santo Tomás, Bogotá, Colombia; Master in Linguistics from Caro y Cuervo Institute, Colombia. She holds a Bachelor Degree in Languages from Universidad del Atlántico, Colombia. She is currently a tenured lecturer at Universidad Distrital Francisco José de Caldas at the Doctorado Interinstitucional en Educación (ELT Education) and the Bachelor of Arts in English as a foreign language. pilarmendezr@hotmail.com http://orcid.org/0000-0001-9284-4611

Received: June 10th, 2019. Accepted: December 7th, 2019

This article is licensed under a Creative Commons Attribution-Non-Commercial-No-Derivatives 4.0 International License. License Deed can be consulted at https://creativecommons.org/licenses/by-nc$\mathrm{nd} / 4.0 /$ 
Jairo Eduardo Soto-Molina,

Pilar Méndez

Keywords: cultural alienation, English as a foreign language, linguistic colonialism, textbooks, teaching of culture.

\section{Resumen}

El propósito de este documento es examinar y comparar los conceptos de colonialismo lingüístico y alienación cultural en libros de texto universitarios para la enseñanza del inglés como opuestos a las teorías sobre cultura en el giro decolonial. Se establecieron categorías dicotómicas basadas en el análisis del componente cultural de los libros de texto para enseñar inglés. El corpus se centró en seis libros de texto de editoriales multinacionales, utilizados en Colombia durante el periodo 2006-2018. Se utilizaron procedimientos de análisis documental para discutir temas emergentes en relación con los componentes culturales desde una perspectiva crítica que devela prácticas imperialistas. Los resultados muestran que el contenido de los libros de texto maneja altos niveles de carga alienante, componentes superficiales de cultura e instrumentalización de la persona sumisa que favorece al inglés como cultura dominante y no ofrece posibilidades para acoger la interculturalidad en contextos de enseñanza del inglés como lengua extranjera.

Palabras clave: alienación cultural, inglés como lengua extranjera, colonialismo lingüístico, libros de texto, enseñanza de la cultura.

\section{Introduction}

The recent contributions that intercultural studies have made to the teaching of languages have introduced the idea that intercultural competence develops communicative competences. Worldwide, this relation intercultural-communicative competence has been studied by teachers and researchers (Agudelo, 2007; Álvarez, 2014; Clouet, 2012; Gómez, 2015; Liddicoat \& Scarino, 2013; Meadows, 2016) showing that there are different ways to tackle cultural relations when teaching English in EFL settings. However, the teaching of English in EFL contexts is a complex endeavor that makes teachers face some problematic issues emerging in the form of (i) dilemmas to overcome the imbalance between the two cultures in contact (Stern, 1983), (ii) contradictions between the culturally related ideological components of materials and teachers' practices and discourses (Bonilla Medina, 2008; Gómez, 2015; Muhammad, 2015), and (iii) challenges to contest canonical and homogenizing ways to work on the local cultural context via policies (Fandiño, 2014; Macías, 2010) or to embrace critical pedagogies to work with intercultural approaches (Bonilla Medina, 2012).

Cultural components of textbooks and the ways these components are displayed to teach English can be instruments of a dominant cultural reproduction if these components are not intercultural oriented. Several works have dealt with materials and textbooks (Bonilla Medina, 2008; Castañeda Usaquén, 2012; Gómez, 2015; McConachy \& Hata, 2013) to problematize the relation of intercultural competence and language in the ELT field. Their contributions are valid for denouncing power imbalance to the detriment of the stability between languages in contact. In this particular work, we will extend the discussion via 
embracing some ideas from decolonial thought (Grosfoguel, 2011; Kumaravadivelu, 2008; Macedo, 2000; Pennycook, 1998, 2006, 2008) in relation to linguistic colonialism, while contesting some imperialism practices identified in textbooks for English language teaching in Colombia.

Nowadays, the discussion of linguistic colonialism has regained resignification as regards the value of EFL teachers' lives and work experiences, along with the skills acquired from their practices to position their role as cultural actors and mediators in which their relation to language is paramount to the construction of their identities and teaching practices. At university levels, teachers are not the only ones who control the entire teaching-acquisition / learning process. There are other cultural agents at stake such as the students and the materials used for teaching English. Some universities in the country have privileged a type of material (textbooks, audio and visual material) oriented toward the acquisition of English as a target language. In doing so, the local context/culture has been disregarded and EFL teachers have been the ones adapting the material to cover intercultural features ignored in the textbooks. It means a move to create cultural awareness and tackle cultural displacements of local culture.

As Cortazzi and Jin (1999, pp. 209-210) point out, neither the teacher nor the students, the textbooks or materials, are subjects alien or passive concerning (or as regards) cultures. Personal views and constructions are confronted when texts or materials provide certain knowledge and certain values. The ways teachers and students respond to it might unveil colonization processes if they do not problematize the cultural component of textbooks taking into account their teaching-learning context.

In our view, forms of understanding cultures bear an undeniable ideological and political burden which influences the construction of identities and opinions that constrain the subject in transcendental determinations within students' society in which their own being is obscured. For instance, some textbooks emphasize the image of the native speaker (man, white, heterosexual) in a superior relation or position to other interactants in dialogues. Indeed, this type of constructions is conducive to consolidate certain deficient practices, prejudices and stereotypes while at the same time strengthening or weakening local or national awareness.

We analyzed the selection of contents for the EFL courses based on their intercultural relevance. It means English language textbooks were confronted as to their culture negotiation meaning to trace their treatment given to the cultural component, treatment given to persons, levels of alienation and interaction of cultures. Theoretically, these analytical categories are based on the dialectical relationship that underlies the binomial language-culture, which serves as a basis for didactic proposals tending to the integrative development of linguisticcultural knowledge in EFL learners. In this sense, this article is pertinent because it analyzes 
Jairo Eduardo Soto-Molina,

Pilar Méndez

information collected from data as succinctly as possible, which allows applying a concept of interculturality in the variable of the changeable local context. We try to clamor for a better understanding of our local education in order to cast light upon the type of materials that universities have selected and their colonialism effects as consequences (Pennycook, 1998).

\section{The Role of Multinational Publishers}

Textbooks as materials to teach a content (English, science, religion, etc.) are value-laden approaches due to the selection and organization of content, the promotion of popular ideas over others, the layout of images and what these represent, linguistics codes and social norms, and the editors' and authors' personal agendas and sets of beliefs; aspects which depict a non-neutral domain of knowledge production. Having this in mind, we may see that English language textbooks have been considered signs of neo-colonial practices (Pennycook, 2007; Tollefson, 2000) that promote one-language-one-culture in relation to an idealized self and lifestyle close to the native linguistic model that teaches how to speak and what type of social and normalized rules and rituals must be respected and repeated.

For this reason, the role played by publishing houses in Colombia has been criticized by several scholars (Bonilla Medina, 2008; Castañeda Usaquén, 2012; Gómez, 2015, Ramos Holguín, 2013; Rico Troncoso, 2012, among others) that have raised awareness about the imbalance of power- cultural relations in textbooks. Despite the criticism, publishing houses remain deaf to these critiques and the materials sold still promote a one-language-one-culture curriculum approach. This resembles very closely the colonial discourses characteristic of linguistic imperialism. Indeed, colonialism as a consequence of linguistic imperialism (Pennycook, 1998) perpetuates a set of discourses and practices that produce a submissive or dependent culture (the ignored culture) while increasing their own set of cultural values (the valid culture).

Furthermore, in EFL contexts, the selection of English language textbooks and materials monoculturally-focused contradicts the political consideration of Colombia as a multi-ethnic and multicultural nation (De Mejía, 2006; Guerrero, 2010). It means that this decision is not only pedagogical but political and as a nation grants multinational publishing houses certain concessions to set linguistic and cultural principles for the languages education curricula. An alternative way to respond to this, from a decolonial viewpoint, is to design an emancipatory and decolonizing curriculum that respects the English-speaking culture but also respects the local (Colombian) culture, taking into account the political implications for teaching/ teacher education programs. It means an exercise of resistance to linguistic imperialism (Canagarajah, 2013) by appropriating the language and also by identifying and denouncing colonial situations and practices. 
The following chart presents the way publishing houses introduce themselves to the public eye:

Table 1. Publishing Houses and Their Missions.

Publishing Houses

Cambridge UP/The oldest publishing house. We are Cambridge University Press, the oldest publishing house in the world and the University of Cambridge's own publishing company. In fact, we are actually one of the University's own departments. Our mission is to filter through and give shape to all the knowledge the University generates: Sciences, Humanities, Linguistics, etc. We've been involved in teaching for five hundred years and, in the last century, we've become specialized in English language teaching courses.

McGraw Hill/ Our vision is to unlock the full potential of each learner. Our mission is to accelerate learning. We accomplish this by creating intuitive, engaging, efficient, and effective learning experiences - grounded in research. We're helping create a brighter future for students worldwide by applying our deep understanding of how learning happens and how the mind develops. Learning science is the key.

MacMillan/Macmillan Education is a global publisher with a local presence. You'll find us operating in over 120 countries worldwide, but our global vision does not take away from our regional focus. Working locally allows us to get close to the people who matter - the students, teachers, institutions and educational authorities who use our products and with whom we've developed real and lasting relationships. Today, Macmillan Education is a name synonymous with high-quality publishing around the world.

Pearson/ Our vision is to have a direct relationship with millions of lifelong learners and to link education to the way people aspire to live and work every day. To do that, we'll collaborate with a wide group of partners to help shape the future of learning. We believe that we all need to embrace lifelong learning, continuously acquiring new knowledge and skills to thrive in an ever-changing and increasingly connected world.

Oxford/ At Oxford University Press we have a clear mission which informs everything we doto create the highest quality academic and educational resources and services and to make them available across the world. We share the University's uncompromising standards, defining qualities, and belief in the transformative power of education to inspire progress and realize human potential.

Source: Publishing houses main pages

As can now be seen, publishing houses' missions are clearly oriented to promoting English language and culture, even when the core definition given to English embraces it as an international language. Pay attention to the highlighted segments to see an overall idea of their political and cultural implications. 
Jairo Eduardo Soto-Molina,

Pilar Méndez

We would like to close with a final remark in this regard: in multicultural relationships, any one of the cultures or languages with which one has contact is not superior to any other. Each culture and, consequently, each language is valid and equal in importance to the others; being different does not imply superiority or inferiority, under any circumstances.

\section{Linguistic Imperialism from a Decolonial View}

An epistemological approach to learning that embraces justice must be emancipatory, decolonial, and liberating from linguistic and cultural imperialism. It means an effort to dismantle overt and covert practices in ELT which perpetuate a monolingual view of English teaching in contexts in which other languages and cultures co-exist. Much time has elapsed since English was imposed by various forces in colonial times (Barrantes-Montero, 2018), but currently, imposition of English operates with the awareness or not completely unaware alliances of governments, policies, and some English language teachers. In this section, we will refer to linguistic imperialism to tackle one of its consequences, linguistic colonialism (Farrel, 1994; Mendoza, 2002; Pennycook, 1998): a political and cultural process in which a majority language is imposed through acculturation practices that lead to the loss of local cultures and languages.

Linguistic imperialism (Phillipson, 1992) has had a dramatic impact on contemporary ELT, exposed worldwide to denounce injustice, discrimination, and culture assimilation (Agudelo, 2007; Álvarez, 2014; Clouet, 2012; Gómez, 2015; Liddicoat \& Scarino, 2013; Meadows, 2016; Phillipson, 1994, 1996, 2003, 2006, 2009). These denounced facts have served to identify other types of power, much more effective, used to colonize beings, knowledge, and actions (Maldonado-Torres, 2007), making possible the acceptance of English linguistic colonialism as natural and inevitable.

Phillipson (1992) has taken into account the original work done by two key academics in the field, such as Pennycook (1998) and Canagarajah (2000) who argue that the transfer of English is by no means a one-way process as, "The two levels, macro and micro, global and local, do not exclude each other, quite the opposite" (Phillipson, 2009, p. 16). This functioning can be identified in some Latin American countries (Colombia, Chile) at both macro and micro levels; for instance, the ways in which local policies accommodate a new form of understanding the bilingualism concept. This new comprehension of bilingualism allows the establishment of an English-only model, while the use of Spanish is restricted in most EFL classrooms. This approach is also supported by the use of textbooks produced by multinationals such as McGraw Hill, Prentice Hall, MacMillan, and Longman, among others, that "rule" the way local English language teachers have to teach. The content of textbooks is bloated with features of English culture (national symbolism, habits, and cultural ways of 
problem solving) so that their cultural contents offer little or no space to negotiate other ways of thinking, feeling, and acting.

Although Phillipson's work came to light back in 1992 and many others since then have added to it, linguistic colonialism as a direct consequence of neo-colonial practices in education is still increasing. For this reason, the study of linguistic imperialism is still relevant and necessary (Becker, 2003; Calvet, 2005) in these times in which globalization is the lure for imperial purposes. The increase of university degrees earned in America, Africa, Oceania, Asia, and all of Europe, as well as the continuous migration to these zones for educational purposes are presented as some of the structural reasons why English continues to dominate other cultures. The ideology of the nation-state incorporates or promotes English as the language of business, technology, commerce, and even its status as a lingua franca (Crystal, 2003), which is needed to set conditions for a modern and globalized world. The ways universities and educational institutions have been organized to guarantee some conditions to strategically maintain the preference for English is a matter of strong criticism. Indeed, what has been known as the commercialization of education commodifies the conditions to perpetuate a linguistic colonialism to the detriment of minority languages and culture. These new forms of colonization (in the name of globalization, modernity, and productivity) are dangerous because these do not only affect educational practices in their attempt to homogenize a one-language-one-world nation, but they also affect learners' processes of identity (and difference) construction to affirm other conditions of existence within their own cultures.

Within a decolonial point of view, it is truly needed to decolonize people's minds, embracing a critical understanding of how ELT is made up of political and cultural forces which compel actions. It means being alert and responsive to the ways English language teachers can be used as instruments of these new forms of colonization because of their relational identification to the English language. So, questions of these kinds should be a constant preoccupation during lesson planning and teaching: What types of actions are recommended to resist linguistic colonialism while teaching English? What strategic decisionmaking process favors a just and equitable teaching style in regard to culture?

\section{Linguistic Colonialism in Colombia and Latin America}

Colombia and Latin America have lived through raw processes of decolonization since the arrival of the Spaniards. However, much of population is still learning to understand what decolonization means in relation to economics, politics, and social policies at a macro level dimension. It is still hard to spot colonial situations in daily practices when a discourse such as English as the language of triumph and success gains popularity and acceptance at a micro level dimension. The preference for English is not just a question of policy makers since people 
Jairo Eduardo Soto-Molina,

Pilar Méndez

as consumers of products also negotiate with the ideological set of values that surrounds its promotion as a lingua franca for business, socialization, and success.

Calvet (1981) addresses these linguistic facts throughout history to demonstrate the ideological preparation that allows the colonial discourse to be valid and produce lethal results such as glotophagy (a process of language acculturation), based on the belief that there are higher and lower languages to exercise linguistic colonialism over the speaking peoples of the languages devoured by the hegemonic language. His analysis reveals the existence of a brand of ideological dominance represented in the communities that guarantee a subsequent practice. For Calvet (1981), it is not a coincidence that the theory of language is at the service of the different forms of colonialization.

The multinational publishers have a clear colonial purpose in the production of their texts, according to Calvet (2005). These books bear a deep burden of cultural alienation because the cultural content is almost targeting the foreign culture while the students' own culture is ignored (Canagarajah, 2000; Ozdemir \& Rahimi, 2013; Ryan, 1998, 2003). Indeed, processes of whitening in which race, language prestige, habits, and values from English dominant circles are used to universalize their identities to the detriment of minoritized languages' set of cultural values and identities (Castañeda-Peña, 2018). The alienating effects foster glotophagy and also the abandonment of difference. For that reason, English language classrooms are a site to either accept or resist these effects in order to embrace intercultural practices.

Moreover, the social struggle of languages has been a constant in developing countries in which "linguistic loan" has been an exercise to borrow, adapt, and receive more easily words coming from dominant languages to minor ones. Calvet (1981) disagrees with the term "linguistic loan". He sees it as a way to accept linguistic and cultural colonization. In his view, each language must create its repertoire of its own expressions as the Latinized pronunciation of the term "CD". In this process, a resistance to linguistic colonization can be observed.

Resistance to colonization has been indeed linguistically productive in prominent cases. Creole, for example, emerged as a new language because it resists the ravages of colonization, precisely because of the strength of culture. The palenquero language (in Colombia) is also a perfect example of resistance to Spanish colonization. It means that language users have found ways to exercise power to avoid being positioned as a submissive culture.

The role of English language teachers is very important to find ways to construct representations of target languages related cultures (Menard-Warwick, 2009). In doing so, (whether incorporating cultural topics, discursive resources, or intercultural material) a sense of one's own cultural appropriation must be activated while confronting textbooks 
and materials culturally oriented toward English only. A way to do it is via embracing an intercultural pedagogy to gain a balance between interactions of cultures in contact.

\section{Interculturality to Resist Linguistic Colonialism}

Intercultural pedagogies have arisen as an epistemological situated response to ensure cultural balance and appropriation in societies in which struggles to co-exist depend on discourses and actions to contest practices of homogenization and universalization (Hrvatić, 2007). The rights to be different and preserve a people's own identities, languages, and cultural features in ELT education have been pedagogically tackled within multidisciplinary projects in which teachers not only raised awareness of the inadequacies of monolithic views of culture in existing approaches and means for teaching English, but also provided relevant knowledge to embrace equitable and non-discriminatory principles to relate to languages in contact.

In EFL contexts in which policies and institutional decisions favor an English-only cultural approach, most of the time teachers are forced to work and follow textbooks supporting that approach. In some cases, when there are opportunities to exercise autonomy, teachers adapt the contents to the Colombian culture, offering alternative ways to discuss deep cultural aspects in relation to superficial ones to target content languages (English \& Spanish) or even other cultures. In other words, "they find ways of having an existential relationship in the pursuit of getting to be themselves"' (Márquez-Fernández, 2006, p. 154).

Interculturality as a political endeavor of education "increases awareness and respect of difference, as well as the socio-affective capacity to see oneself through the eyes of others" (Kramsch, 2005, p. 553). In this respect, it is necessary to analyze the debate about the global knowledge society and globalization as a homogenizing phenomenon of cultures and terminator of languages and dialects guided by a hermeneutical methodology promoted in textbooks and cultural materials monolithically oriented. Within a critical view of culture, based on intercultural philosophy as a theoretical and practical basis, the inclusion of minoritized cultures is an emancipatory expression (Burch, 2005).

According to Betancourt (1994), the goal of interculturality is to enrich, grow, and maintain cooperatively united the two cultures in contact; to be more flexible, tolerant, and effective citizens in communication based on cultural rights; without leaving aside the respect that must exist for other cultures (Taylor \& Morales, 2006). For interculturality, all social action is expressed through discourse and its meaning to be described, manifested, reported, analyzed, and interpreted to make the world visible and understandable.

\footnotetext{
Original in Spanish. Our translation.
} 
Jairo Eduardo Soto-Molina,

Pilar Méndez

\section{Materials and Methods}

Documentary analysis procedures were implemented to read, revise, compare, and contrast the cultural content proposed in the six English language textbooks of multinational publishers. The analysis was done through the identification of coding content components (Bowen, 2009) that constitute some dichotomous notions in which some relations such as occurrence/presence/absence/repetition and content analysis are fundamental to question textbooks (O'Leary, 2014). In doing so, the following categories were constructed: presence of Colombian (or Latin American) student culture, incorporation of superficial or deep components of culture, levels of alienation burden, instrumentation to the submissive person, and interaction of cultures.

Corpus organization. To facilitate the identification process, textbooks of the multinational publishers were assigned a letter in their respective order A: Cambridge: Empower, B: McGraw Hill: Connect for English, C: MacMillan: Language Hub, D: Pearson: The Global Scale of English (GSE), E: Oxford: English File, F: Longman: Stand out.

\section{Results and Discussion}

Five thematic content components were identified and contrasted within content textbook analysis in relation to culture from a critical questioning in which local elements and intercultural principles we advocate for are integrated as part of the discussion. The main question for tackling cultural content in the six English language textbooks was formulated as follows: To what extent do the contents in these textbooks promote interculturality?

Presence of Colombian students' local culture. The first data allowed us to compare and contrast the validity of the English language lessons incorporated in the textbooks in relation to aspects of Colombian or at least Latin American culture. In short, the data generated show that the local culture has little or no presence in the textbooks analyzed. If it is understood that English is a language for international communication, a description of different sociocultural contexts must be provided as an extension of the places, cities, 20 and cultural devices presented in pictures and dialogues which belong to English language mainstream cultures. Most of the pictures and their descriptive and referred texts were introduced resembling the idea of the American dream with notions of freedom as well as economic and sociocultural prosperity.

The presence of local or Latin American culture is very scarce as can be seen from the percentages of each text in the above graph, in which Language Hub was the textbook with the highest Latin American cultural reference. 


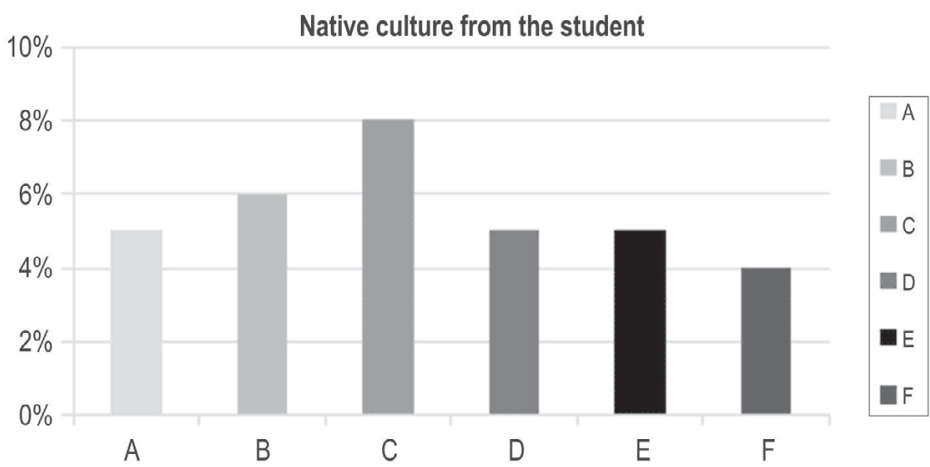

Graph 1. The student's native culture.

Superficial and deep components of culture. All units and pages of the textbooks were examined to detect those activities in which culture was incorporated. Each topic was classified according to surface culture (emblematic and representative elements) and deep culture features (beliefs, values, and ideologies) (Gómez, 2015). Topics superficially addressed were extensive in comparison to those with a deeper cultural treatment. Topics such as holidays, different sites, food, and famous people were classified taking into account their static, neutral, and homogeneous introduction. In addition, topics that seemed to be more complex were examined according to their possibilities to create controversial or congratulatory agreements, heterogeneous options of reactions, and transformative features

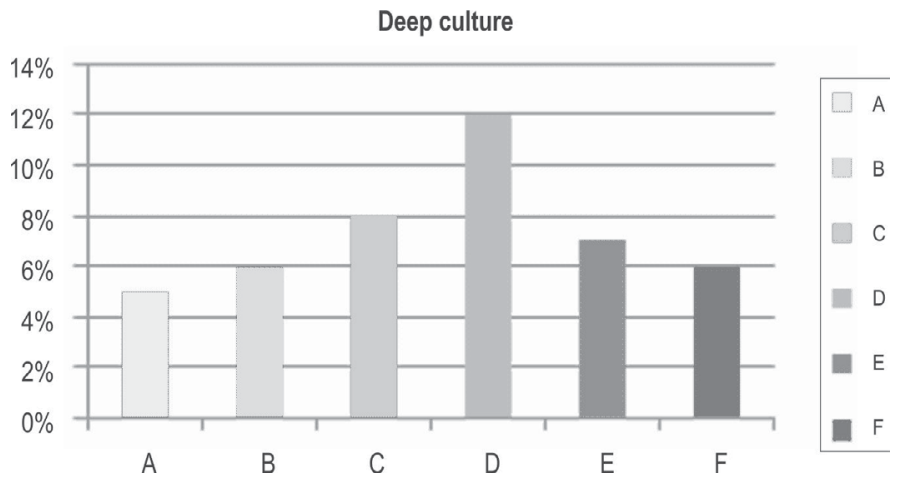

Graph 2. Deep culture. 
Jairo Eduardo Soto-Molina,

Pilar Méndez

during their presentation. These topics dealt with family ties, ethics, ownership, space and proxemics, sex roles, ceremonies and rituals, as well as values and ideologies.

As can be observed, the textbook GSE had a majority presence of topics of the kind, followed by the Language Hub textbook. In general terms, the overall percentage of topics dedicated to fostering intercultural discussions based on a deep treatment of culture is low. It means that teachers who embrace intercultural approaches must integrate or complement the material to extend the discussion.

Levels of alienation burden. The alienating burden that underlies these textbooks is extremely high given the percentage of topics and interactions in which, for example, appropriate phrases and behaviors are portrayed as the rule. Some role plays were aligned to sustain men's leadership roles while interacting with women. Other dialogues were constructed to determine cultural patterns or rituals (to give compliments, apologize for everything, to show encouragement, etc.). In some topics about tourism and marketing,

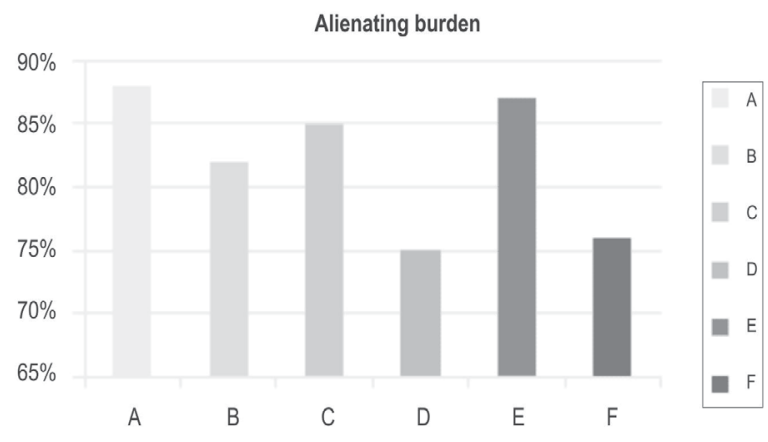

Graph 3. Alienating burden.

some generalizations were made about the supremacy of the US dollar as the currency for international trade and marketing, and English language use to communicate with others in touristic places. Also, some symbols and cultural artifacts (signs, objects) were introduced with a sense of cultural superiority, hence to be emulated and recognized worldwide.

Some situations in which learners had to imagine how the future could be were located in cities such as New York, Washington D.C., London, Australia (to mention a few), depicting an illusionary reality for English language learners.

Alienation as the sense of (self) estrangement can be experienced by English language learners who do not recognize themselves in social situations or conventionally established 
values from the cultural components of English taught in textbook lessons. The absence of the learners' own culture can be experienced also as a lack of context-based reality to react or respond to the target language without experiencing an acculturation process.

This category, alienating burden, was the second highest category among the others. Graph 3 above showed that four of the textbooks have more than $80 \%$ of alienating oriented content to impose a set of values, habits, rituals, and behaviors as norms. The ways these contents are presented in the textbooks articulate tacitly arguments that can be classified into three groups (Phillipson 1992), related to skills (intrinsic arguments to English: what English is), resources (extrinsic arguments to English: what English has), and uses (arguments in English), regarding the functionality of English: (what English does).

Instrumentation to the submissive person. The textbooks promote a submissive culture of the possible emigrant to English-speaking countries. In general, submissive people tend to avoid discrepancies, no matter how minimal. They usually make sacrifices to avoid these "clashes of wills", dedicating time, effort, and resources in order not to antagonize others, or simply feeling impatient or angry. In this way, an instrumentation is made to the submissive person who seeks the protection or influence of the native of English and even mental dependence. Some work and academic situations represented in dialogues and readings were guided to replicate behaviors in which native English speakers were in control of situations. Also, these situations included ritualized patterns in which working conflicts were closed with a redundancy notice as something normal and culturally acceptable. In psychology, it is called theory of submission or learned helplessness. Learned (impotence) is a term emerging from psychology that refers to the condition of a human or animal that has "learned" to behave passively, with the subjective feeling of not having the capacity to do anything and not responding even though there are real opportunities available to change the

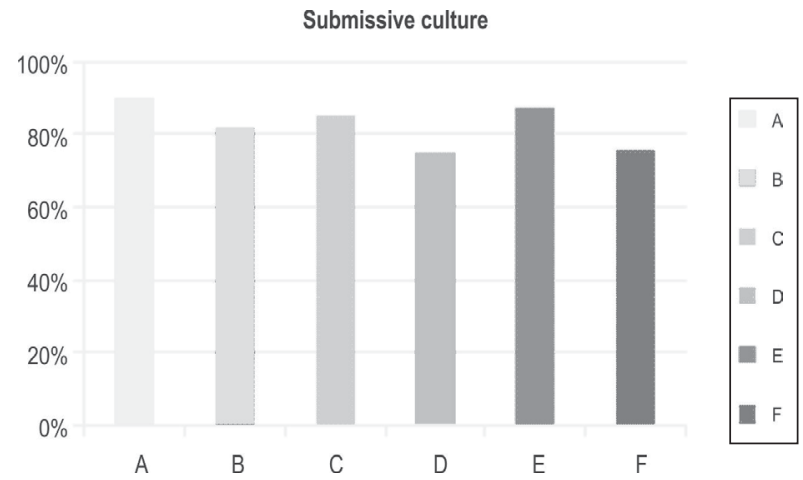

Graph 4. Submissive culture. 
Jairo Eduardo Soto-Molina,

Pilar Méndez

aversive situation. "That is the way it is" became a norm based on an idealized English-native culture. In this way, the submissive person tries not to attract the attention of others in order to avoid conflicts and humiliating situations.

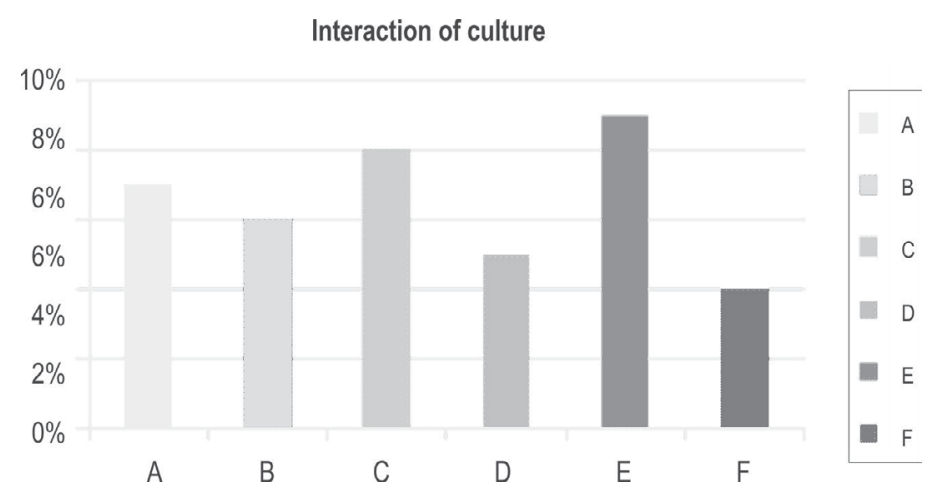

Graph 5. Interaction of cultures.

This graph showed the highest percentages of repetition in ruling people's behaviors as submissive to the English language dominant-culture model. Each textbook reached nearly $80 \%$ of recurrence in this aspect.

Interaction of cultures. It is worth mentioning that this final category goes hand in hand with the first one (presence of Colombian or Latin American culture). From an intercultural point of view, the possibilities to give both cultures (foreign and native) the same dimension of deep cultural treatment are scarce. Even when some Latin American places are introduced, the possibilities to make comparisons at the same level of abstraction and coverage are dissimilar.

That is to say that an effective interaction between cultures as Graph 5 indicates is not represented. The native culture of English-whether British, American, Canadian or Australian — is given prevalence and superiority.

\section{Conclusion}

This research article analyzed the cultural components of six English language textbooks used in Colombian universities to pinpoint their monolingual cultural approach as detrimental to embracing intercultural pedagogy. Although this fact can be illustrated through the categories discussed above, these research results are an invitation to English 
language teachers and university curricula administrators/designers to favor multicultural textbooks or the inclusion of a balanced intercultural-oriented content of both languages (Spanish and English) to contribute to the development of a bilingual education curricula. The role of English language teachers is of paramount importance to extend the intercultural dimension of languages teaching in scenarios where textbooks are culturally biased and used as acculturation instruments that favor linguistic colonialism.

Acknowledgments. Authors express their gratitude to Francisco Pérez-Gómez for reviewing the manuscript and to Randall Davis Barfield for his professional services as proofreader.

\section{References}

Agudelo, J. (2007). An intercultural approach for language teaching: Developing critical cultural awareness. Íkala, Revista de Lenguaje y Cultura, 12(18), 185-217.

Álvarez, J. A. (2014). Developing the intercultural perspective in foreign language teaching in Colombia: A review of six journals. Language and Intercultural Communication, 14(2), 226244. http://dx.doi.org/10.1080/14708477.2014.896922.

Barrantes-Montero, L. G. (2018). Phillipson's linguistic imperialism revisited at the light of Latin American decoloniality approach. Revista Electrónica Educare, 22(1), 1-19.

Becker, G. S. (2003). The quantity and quality of life and the evolution of world inequality. Springer, USA: National Bureau of Economic Research.

Betancourt, R. F. (1994). Filosofía intercultural. México D.F.: Universidad Pontificia de México.

Bonilla Medina, X. (2008). Evaluating English textbooks: A Cultural Matter. HOW Journal, 15(1), 167-191.

Bonilla Medina, X. (2012). TEFL educational principles: A proposal for changing times. Colombian Applied Linguistics Journal, 14(2), undefined-undefined.

Bowen, G. A. (2009). Document analysis as a qualitative research method. Qualitative Research Journal, 9(2), 27-40.

Burch, S. (2005). Sociedad de la información/Sociedad del conocimiento. Palabras en juego, 54-78.

Calvet, L. J. (1981). Lingü̈stica y colonialismo: Breve tratado de globofagia. Madrid: Editores: Gijón.

Calvet, L. J. (2005). Lingüística y colonialismo: Breve tratado de glotofagia. Buenos Aires: FCE.

Canagarajah, A. S. (2000). Resisting linguistic imperialism in English teaching. New York: Oxford University Press.

Canagarajah, A. S. (2013). Agency and power in intercultural communication: Negotiating English in translocal spaces. Language and Intercultural Communication, 13(2), 202-224. 
Jairo Eduardo Soto-Molina,

Pilar Méndez

Castañeda Usaquén, M. (2012). Adolescent students' intercultural awareness when using culturebased materials in the English class. Profile: Issues in Teachers' Professional Development, 14(1), 29-48.

Castañeda-Peña, H. (2018). Structuralist, poststructuralist and decolonial identity research in English language teaching and learning. In Castañeda-Peña, H., et al., ELT Local Research Agendas I (pp. 17-34). Bogotá: Editorial Universidad Distrital.

Clouet, R. (2012). Studying the role of intercultural competence in language teaching in upper secondary education in the Canary Islands, Spain. Onomázein, 26, 309-334.

Cortazzi, M., \& Jin, L. (1999). Cultural mirrors: Materials and methods in EFL classroom. In E. Hinkel (ed.), Culture in second language teaching (pp. 196-219). Cambridge: Cambridge University Press.

Crystal, D. (2003). English as a global language (2nd ed.). Cambridge, England: Cambridge University Press.

De Mejía, A. (2006). Bilingual education in Colombia: Towards a recognition of languages, cultures and identities. Colombian Applied Linguistics Journal, 8, 152-168.

Fandiño, Y. J. (2014). Teaching culture in Colombia Bilingüe: From theory to practice. Colombian Applied Linguistics Journal, 16(1), 81-92.

Farrel, C. (1994). Linguistic colonialism and the survival of subaltern languages: English and Irish. The Public, 1(3), 55-65.

Gómez, L. F. (2015). The cultural content in EFL textbooks and what teachers need to do about it. Profile: Issues in Teachers' Professional Development, 17(2), 167-187.

Grosfoguel, R. (2011). Decolonizing post-colonial studies and paradigms of political-economy: Transmodernity, decolonial thinking and global coloniality. Transmodernity: Journal of Peripheral Cultural Production of the Luso-Hispanic World, 1(1), 1-38.

Guerrero, C. (2010). The portrayal of EFL teachers in official discourse: The perpetuation of disdain. Profile: Issues in Teachers' Professional Development, 12(2), 33-49.

Hrvatić. N. (2007). Interulturalna pedagogija: nove paradigme. Pedagogijska istraživanja, 4(2), 241 254.

Kramsch, C. (2005). Foreign language between knowledge and power. Applied Linguistics, 26(4), $545-567$.

Kumaravadivelu, B. (2008). Cultural globalization and language education. New Haven, CT: Yale University Press.

Liddicoat, A., \& Scarino, A. (2013). Intercultural language teaching and learning. Malden, MA: WileyBlackwell.

Macedo, D. (2000). The Colonialism of the English only movement. Educational Researcher, 29(3), 15-24.

Macías, D. F. (2010). Considering new perspectives in ELT in Colombia: From EFL to ELF. HOW Journal, 17(1), 181-194. 
Maldonado-Torres, N. (2007). Sobre la colonialidad del ser: contribuciones al desarrollo de un concepto. In S. Castro-Gómez \& R. Grosfoguel (Eds.), El giro decolonial. Reflexiones para una diversidad epistémica más allá del capitalismo global (pp. 127-167). Bogotá: Iesco-Pensar-Siglo del Hombre Editores.

Márquez-Fernández, Á. B. (2006). El rol de integración política de la ética en la sociedad civil. Polis Revista Latinoamericana 1(13), 1-9.

McConachy, T., \& Hata, K. (2013). Addressing textbook representations of pragmatics and culture. ELT Journal, 67(3), 294-301.

Meadows, B. (2016). Culture teaching in historical review: On the occasion of ASOCOPI's fiftieth anniversary. HOW Journal, 23(2), 148-169.

Menard-Warwick, J. (2009). Co-constructing representations of culture in ESL and EFL classrooms: Discursive faultlines in Chile and California. The Modern Language Journal, 93(1), 30-45.

Mendoza, A. M. (2002). Sobre el imperialismo lingüístico y el idioma inglés. Realidad: Revista de Ciencias Sociales y Humanidades, 88, 511-530.

Muhammad, J. S. (2015). Textbooks and ideology. Asian Journal of Humanities and Social Studies, $3(6), 575-581$.

O'Leary, Z. (2014). The essential guide to doing your research project ( $2^{\text {nd }}$ Ed.). Thousand Oaks, CA: SAGE Publications, Inc.

Ozdemir, A., \& Rahimi, A. (2013). Classroom environment and EFL students' feelings of alienation: Reflections on Bahcesehir University setting. Journal of Education and Practice, 4(6), 48-54.

Pennycook A. (2007). ELT and colonialism. In J. Cummins \& C. Davison (Eds.), International handbook of English language teaching. Springer International Handbooks of Education (Vol. 15) (pp. 13-24). Boston, MA: Springer.

Pennycook, A. (1998). English and the discourses of colonialism. London, New York: Routledge.

Pennycook, A. (2006). Global Englishes and transcultural flows. New York: Routledge.

Pennycook, A. (2008). Translingual English. Australian Review of Applied Linguistics, 31(3), 30-1.

Phillipson, R. (1992). ELT: The native speaker's burden? ELT journal, 46(1), 12-18.

Phillipson, R. (1994). English language spread policy. International Journal of the Sociology of Language, 107, 7-24.

Phillipson, R. (1996). Linguistic imperialism: African perspectives. ELT Journal, 50(2), 160-167.

Phillipson, R. (2003). English-Only Europe: Challenging language policy. New York: Routledge.

Phillipson, R. (2006). Language policy and linguistic imperialism. An introduction to language policy: Theory and method. UMB Journal, 346-361.

Phillipson, R. (2009). Linguistic imperialism continued. London: Routledge.

Ramos Holguín, B. (2013). Towards the development of intercultural competence skills: A pedagogical experience with pre-service teachers. HOW Journal, 20(1), 206-225. 
Jairo Eduardo Soto-Molina,

Pilar Méndez

Rico Troncoso, C. (2012). Language teaching materials as mediators for ICC development: A challenge for materials developers. Signo y Pensamiento, 31(60), 130-154.

Ryan, P. M. (1998). Cultural knowledge and foreign language teachers: A case study of a native speaker of English and a native speaker of Spanish. Language, Culture, and Curriculum, 11, $135-153$.

Ryan, P. M. (2003). Foreign language teachers and their role as mediators of language-and-culture: A study in Mexico. Estudios de Lingüistica Aplicada, 37, 99- 118.

Stern, H. (1983). Fundamental concepts of language teaching: Historical and interdisciplinary perspectives on applied linguistic research. Oxford: Oxford University Press.

Taylor J. A., \& Morales, H. V. (2006). Intercultural competence without international experience. 9th Annual ELT Conference. Bogotá: Universidad de La Salle.

Tollefson, J. (2000). Policy and ideology in the spread of English. In J. K. Hall \& W. Eggington (Eds.), The sociopolitics of English language teaching (pp. 7-21). Clevedon: Multilingual matters. 